\title{
MICROBIOLOGICAL AND CHEMICAL CHANGES DURING TWO-PHASE FERMENTATION OF KEFIR
}

Bojana Danilović*, Natalija Đorđević, Dragiša Savić

Faculty of Technology, University of Niš, Leskovac, Serbia

Kefir is a fermented dairy product with the increasing interest for commercial production due to its benefits to human health. It is produced by the combination of alcoholic and lactic fermentation caused by the activity of kefir grains microbiota. Microbiological and chemical changes during the fermentation are driven by the activity of lactic acid bacteria and yeasts present in kefir grains. This paper describes the changes which occur during the kefir fermentation produced by the so-called "Russian method". In this two-phase fermentation, the increase in the number of lactic acid bacteria and yeast was observed. The activity of lactic acid bacteria led to the accumulation of organic acids and, consequently, to the $\mathrm{pH}$ value decrease. This process was followed by the lactose consumption, as the main energy source for microorganisms. On the other hand, yeasts present in the kefir culture induced the increase of the $\mathrm{CO}_{2}$ content during both phases of fermentation. The application of this process can reduce the time needed for the kefir production without the reduction of its desirable sensory characteristics.
(ORIGINAL SCIENTIFIC PAPER) UDC 637.146.2:663.1

Keywords: kefir, kefir grains, lactic acid bacteria, yeasts, chemical changes

\section{Introduction}

Kefir is a fermented dairy product produced by the combination of lactic and alcoholic fermentation induced by kefir grains or kefir cultures in various kinds of milk. Kefir grains are a mix of different microorganisms in polysaccharide matrix consisted of more than 50 different bacterial and yeast strains and a few strains of filamentous fungi $[1,2]$. The most abundant bacterial strains in kefir grains belong to lactic acid bacteria (LAB) [2]. LAB population comprises $65-80 \%$ of total microbiota of kefir grains. Kefir grains consist of lactococci, streptococci and approximately $74 \%$ of heterofermentative and $26 \%$ of homofermentative lactobacilli. Also, up to $10^{5} \mathrm{CFU} / \mathrm{g}$ acetic acid bacteria and $10^{4}-10^{5} \mathrm{CFU} / \mathrm{g}$ yeasts can be isolated from kefir grains [3].

The kefir production can be performed by three different methods. A traditional method involved inoculation of milk directly with $2-10 \%$ of kefir grains and fermentation for $24 \mathrm{~h}$ at the temperature of $20-25^{\circ} \mathrm{C}$. The increase in the production scale led to the development of the twophase "Russian style" kefir production. The traditional way of the production was used in the first phase, while afterwards the grains were separated, and percolate was used for the second phase. For second inoculation, 1-3\% of percolate was used. Today, the industrial production of kefir relies on the use of various complex starter cultures $[4,5]$. Although starter cultures ensure the stability in the production process, this method has some drawbacks.
The disadvantage of the use of starter cultures mainly refers to the lack of taste, in comparison to the traditionally made product [5].

Due to the microbial composition of kefir grains, the main metabolites of the kefir fermentation are lactic acid, $\mathrm{CO}_{2}$ and ethanol. Different spectroscopic and chromatographic analyses have confirmed the presence of organic acids and volatile compounds which have a primary role in the aroma formation, despite the fact that they are present in relatively low concentrations. Besides lactic acid, citric, acetic, propionic, butyric and pyruvic acid were also detected. The main volatile compounds which contribute to the aroma formation are identified as acetoine, acetaldehyde and diacetile [6]. The fermentation process and the amount of main metabolites can be determined by various methods [7].

Tunable diode laser absorption spectroscopy (TDLAS) represents a very precise technique for measuring the concentration and temperature of gaseous molecules for both scientific and industrial purposes [8]. It measures the attenuation of the laser beam during its route through the measuring region [9]. TDLAS uses a high spectral resolution and a tunable diode laser as a light source [10] and it can be successfully used for food industry measurements [9].

The aim of this work was to monitor microbiological and chemical changes during the two-phase fermentation

\footnotetext{
*Author address: Bojana Danilović, Faculty of Technology, University of Niš,

Bulevar Oslobođenja 124, 16000 Leskovac, Serbia

E-mail: danilovic@tf.ni.ac.rs

The manuscript received: November, 27, 2018.

Paper accepted: January, 08, 2019.
} 
of kefir. The changes of the $\mathrm{CO}_{2}$ content in the headspace above the fermented milk was monitored by the instrument based on TDLAS technology.

\section{Experimental}

\section{Kefir fermentation}

Kefir fermentation was performed as a two-phase process in a $500 \mathrm{ml}$ volume bottle equipped with a vent so the sampling could be performed aseptically without the release of the accumulated $\mathrm{CO}_{2}$. In the first phase, $6 \mathrm{~g}$ of kefir grains were inoculated into $300 \mathrm{ml}$ of sterile cow milk ("Imlek", Belgrade, Serbia) with $3.2 \%$ milk fat and incubated for $24 \mathrm{~h}$ at $25{ }^{\circ} \mathrm{C}$. After the fermentation, kefir grains were sieved and the percolate was inoculated into $300 \mathrm{ml}$ of sterile milk in the concentration of $3 \% \mathrm{v} / \mathrm{v}$. The second part of fermentation was carried out at $25{ }^{\circ} \mathrm{C}$ for $14 \mathrm{~h}$. During both phases of fermentation, $\mathrm{pH}$ values were measured in time intervals of $2 \mathrm{~h}$ using a $\mathrm{pH}$ meter (Hanna Instruments HI 9052, Lisbon, Portugal).

\section{Determination of $\mathrm{CO}_{2}$ content}

The $\mathrm{CO}_{2}$ content in the space above the fermented milk was determined by the device based on TDLAS technology, as already described by Danilović et al. [11]. Measurements were done in triplicate in time intervals of $1 \mathrm{~h}$. The results present the mean values of three measurements.

\section{Microbiological analysis}

For microbiological determinations, the samples of fermented kefir were serially diluted in saline $(0.8 \mathrm{~g} / \mathrm{l} \mathrm{NaCl})$ and $0.1 \mathrm{ml}$ of the appropriate dilution was transferred on MRS agar ("Torlak", Belgrade, Serbia) and Sabouraud maltose agar ("Torlak", Belgrade, Serbia) plates for the determination of the number of $\mathrm{LAB}$ and yeasts, respectively. Inoculated plates were incubated at $30{ }^{\circ} \mathrm{C}$ for $48 \mathrm{~h}$ and enumerated. Experiments were performed in triplicate and data represent the mean values.

\section{HPLC analysis}

Organic acids and sugars contents were determined by the method of Güzel-Seydim et al. [6]. Kefir samples (4 g) were mixed with $25 \mathrm{ml}$ of $5 \mathrm{mM} \mathrm{H}_{2} \mathrm{SO}_{4}$ and then centrifuged for $15 \mathrm{~min}$ at $5000 \mathrm{rpm}$. Supernatant was separated, filtered through the $0.45 \mu \mathrm{m}$ syringe filter and analyzed with Agilent 1100 Series system (Waldbron, Germany). Organic acids and sugars were separated on Aminex HPX-87H column $(7.8 \times 300 \mathrm{~mm}$, Biorad Laboratories, USA) thermostatted at $50{ }^{\circ} \mathrm{C}$. The sample volume of $20 \mu \mathrm{l}$ was injected into the mobile phase consisted of $5 \mathrm{mM} \mathrm{H}_{2} \mathrm{SO}_{4}$ under the flow rate of $0.6 \mathrm{ml} / \mathrm{min}$ using the isocratic elution. The separated components were detected by UV (set at $214 \mathrm{~nm}$ ) and RI detectors. The identification of the components was based on the retention time comparison with the retention times of the authentic standards. Organic acids and sugar concentrations were calculated from the calibration curves constructed by using the appropriate standards.

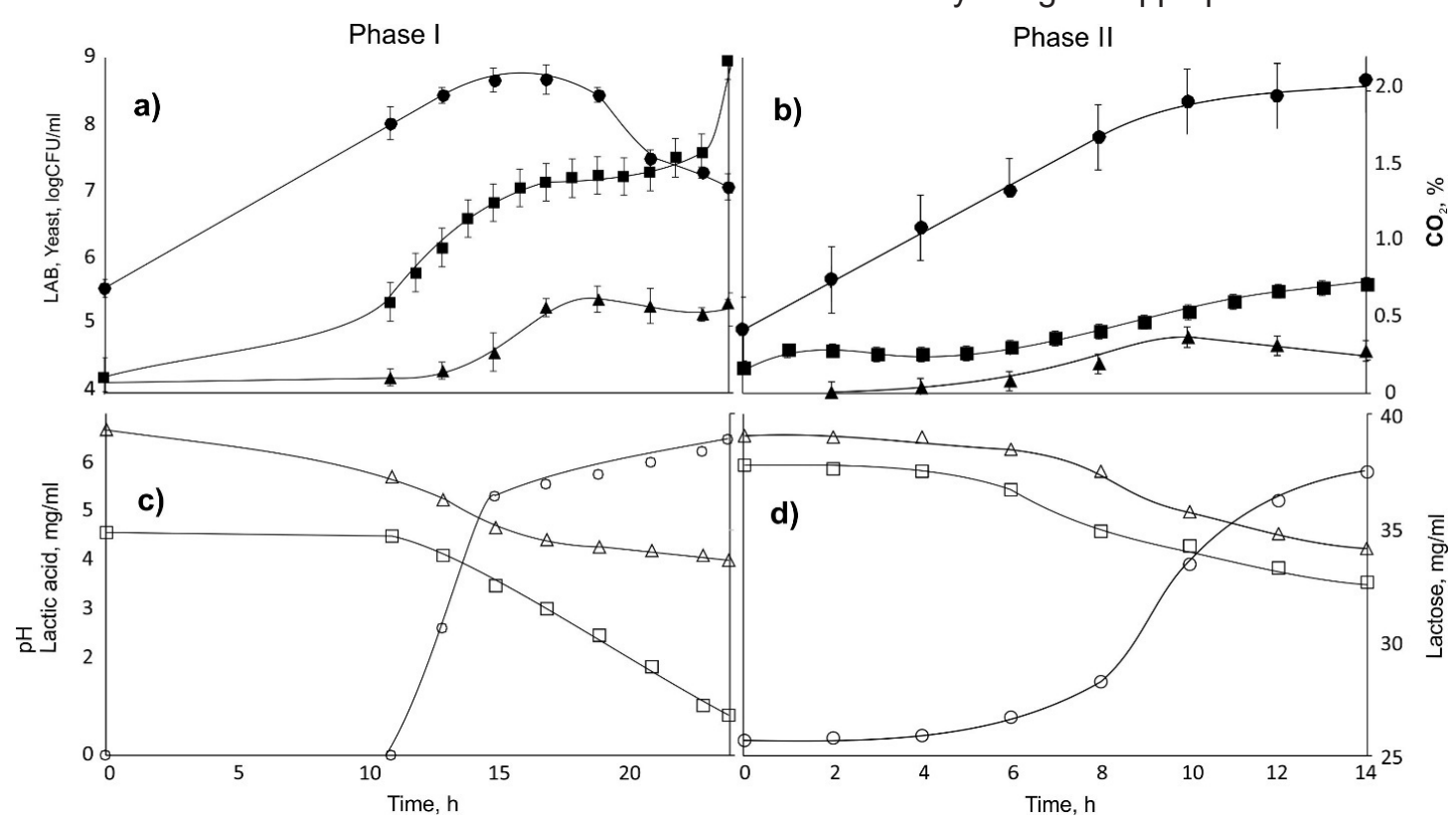

Figure 1. Changes of the number of lactic acid bacteria $(\bullet)$ and yeast $(\boldsymbol{\Delta})$ and $\mathrm{CO}_{2}(\boldsymbol{\bullet})$ content $(\mathrm{a}, \mathrm{b})$ and changes of lactose $(\square)$ and lactic acid $(\circ)$ content and $\mathrm{pH}$ value $(\Delta)(\mathrm{c}, \mathrm{d})$ during the two-phase fermentation of kefir.

\section{Results and discussion}

The change of the number of LAB and yeasts (Fig. 1a and $1 \mathrm{~b}$ ) indicates the increase in the number of these microorganisms. During the kefir fermentation inoculated with kefir grains, the number of LAB increased for $17 \mathrm{~h}$, reaching the value of $8.7 \mathrm{log} C F U / \mathrm{ml}$. After that period, a slight decrease in the number occurred until the end of fermentation while, at the same time, the number of yeasts increased and reached the maximum value of 5.4 
$\log \mathrm{CFU} / \mathrm{ml}$ (Fig. 1a). In the second phase of fermentation, a constant increase of LAB number from 5 log CFU/ $\mathrm{ml}$ to $8.7 \mathrm{log} \mathrm{CFU} / \mathrm{ml}$ can be observed. The yeast growth in this phase was slower and the final value was $4.6 \mathrm{log}$ $\mathrm{CFU} / \mathrm{ml}$ (Fig. 1b). The results obtained for the number of LAB were in accordance with the investigation of Chen et al. [1] who determined the LAB number of $8.0 \mathrm{log} C F U / \mathrm{ml}$ and the yeast number of $6.3 \mathrm{log} \mathrm{CFU} / \mathrm{ml}$ in the kefir made from goat milk and inoculated with kefir grains. On the other hand, Su Oh et al. [12] enumerated the LAB number of $10 \log C F U / m l$ and the yeast number of $4 \log C F U / m l$ in the kefir made from pasteurized cow milk inoculated with commercial kefir starter cultures.

After $12 \mathrm{~h}$ of the first phase fermentation, the $\mathrm{CO}_{2}$ content in the headspace of the milk inoculated with kefir grains increased from $0.1 \%$ to $0.5 \%$ (Fig. 1a) which is in accordance with the increase of the yeast number (Fig. 1a). The continuation of the process was characterized by a rapid increase of $\mathrm{CO}_{2}$ up to $2.2 \%$ (Fig. 1a). Similar results were reported by Zhou et al. [13] where the concentration of $\mathrm{CO}_{2}$ in the space above the Tibetan kefir was $2.1 \%$. In the space above the milk inoculated with kefir percolate, the initial concentration of $\mathrm{CO}_{2}$ was $0.2 \%$ (Fig. $1 \mathrm{~b})$. The increase of the $\mathrm{CO}_{2}$ content was mostly constant with the final value of $0.7 \%$ (Fig. 1b). The increase in the $\mathrm{CO}_{2}$ content in fermented dairy products is mainly the consequence of the yeast activity [11].

During both fermentation phases, $\mathrm{pH}$ values decreased (Fig. 1c and 1d). At the beginning of fermentation, $\mathrm{pH}$ values of milk after the inoculation with kefir grains or percolate were 6.7 and 6.6 , respectively. The $\mathrm{pH}$ value decrease is the consequence of organic acids accumulation during the fermentation [14]. During the first phase, microorganisms of kefir grains adapted the environment of the cow milk and the $\mathrm{pH}$ value decreased to the value of 4.1 (Fig. 1c). Similar was observed with the fermentation of Brazilian kefir inoculated with kefir grains where the final value of $\mathrm{pH}$ after $24 \mathrm{~h}$ was 4.4 [15]. In the second phase of fermentation, microorganisms did not show a high activity in the lactic acid production until the $4^{\text {th }}$ hour of fermentation, so there was no intense change in $\mathrm{pH}$ value. However, after that, a constant decrease of $\mathrm{pH}$ has been observed with the final value of 4.4 after $14 \mathrm{~h}$ of fermentation (Fig. 1d). A similar $\mathrm{pH}$ value was observed during $18 \mathrm{~h}$ of the kefir fermentation [16]. Additionally, the $\mathrm{pH}$ value of 4.4 has been reported as a desirable final value for the kefir fermentation [17]. Since similar $\mathrm{pH}$ value was achieved during $24 \mathrm{~h}$ of fermentation with kefir grains and during $14 \mathrm{~h}$ of fermentation with kefir percolate, it can be concluded that microorganisms of percolate were more adapted to the environment. Both values are in accordance with the data that $\mathrm{pH}$ value of fermented kefir should be in the range from 4.2 to 4.6 [14].

Main metabolites during the kefir fermentation are lactic acid, $\mathrm{CO}_{2}$ and ethanol, but because of the diversity of microbial population in kefir grains, different byproducts (acetic, citric, butyric or propionic acid) can be detected $[15,18]$. During the fermentation, the content of the metab- olites increases due to the lactose utilization by kefir grains microbiota. Lactose is the main carbon source in milk, and it can be easily degraded by some strains of Streptococcus [6] which are often isolated from kefir grains $[2,19]$. The initial concentrations of lactose in milk right after the inoculation with kefir grains and kefir percolate were 34.8 $\mathrm{mg} / \mathrm{ml}$ and $37.8 \mathrm{mg} / \mathrm{ml}$, respectively (Fig. $1 \mathrm{c}$ and $1 \mathrm{~d}$ ). During the first phase of fermentation, the lactose concentration decreased rapidly after $12 \mathrm{~h}$ of fermentation (Fig. 1c) in accordance with the rapid increase of the $L A B$ number (Fig. 1a). During the same time, a decrease in $\mathrm{pH}$ value was observed together with the accumulation of the main metabolite, lactic acid (Fig. 1c). At the end of the first phase of fermentation, the lactose concentration was $26.7 \mathrm{mg} / \mathrm{ml}$ indicating that $23 \%$ of lactose was utilized. This value was similar to the previously reported value for the fermentation of Brazilian kefir produced by direct inoculation with kefir grains, where the lactose utilization was $24 \%$ for the first $24 \mathrm{~h}$ [18]. In the second phase of fermentation, the lactose intake starts after $4 \mathrm{~h}$ (Fig. 1d) together with the increase of the LAB number (Fig. 1b) and the lactic acid concentration (Fig. 1d). Rapid accumulation of lactic acid leads to the decrease of $\mathrm{pH}$ value (Fig. 1d) after 4 $h$ of fermentation. The final concentration of lactose was $32.8 \mathrm{mg} / \mathrm{ml}$ (Fig. 1d). A similar result $(31.1 \mathrm{mg} / \mathrm{ml})$ was obtained for the kefir fermentation of skimmed cow milk [20]. The final content of lactic acid in the first phase was $6.5 \mathrm{mg} / \mathrm{ml}$ (Fig. 1c), and in the second it was $6 \mathrm{mg} /$ $\mathrm{ml}$ (Fig. 1d). The obtained values were almost three times lower than the value reported for Brazilian kefir fermentation [15]. This can be explained by a much higher LAB number in the analyzed Brazilian kefir (12.41 log CFU/ml) compared to the results reported in this paper.

Table1. Changes in citric, malic and acetic acid concentration during the two-phase fermentation of kefir

\begin{tabular}{cccc}
\hline & \multicolumn{3}{c}{ Concentration, $\mathrm{mg} / \mathrm{ml}$} \\
Time, $\mathrm{h}$ & Citric acid & Malic acid & Acetic acid \\
\hline 0 & 1.26 & 0 & 0 \\
11 & 1.20 & 0 & 0 \\
13 & 1.15 & 0 & 0 \\
15 & 1.16 & 0.08 & 0.26 \\
17 & 1.16 & 0.15 & 0.28 \\
19 & 1.16 & 0.09 & 0.30 \\
21 & 1.05 & 0.07 & 0.27 \\
23 & 0.96 & 0.07 & 0.24 \\
24 & 0.93 & 0.12 & 0.27 \\
0 & 1.17 & 0 & 0 \\
2 & 1.20 & 0 & 0 \\
4 & 1.23 & 0 & 0 \\
6 & 1.31 & 0.36 & 0 \\
8 & 1.24 & 0.41 & 0 \\
10 & 1.29 & 0.37 & 0 \\
12 & 1.22 & 0.29 & 0.25 \\
14 & 1.26 & 0.25 & 0.26 \\
\hline
\end{tabular}

Citric acid (Table 1) was detected in the first phase of fermentation in a small concentration, $1.26 \mathrm{mg} / \mathrm{ml}$, which is lower than previously reported, $2.7 \mathrm{mg} / \mathrm{ml}$ [18]. The concentration of citric acid decreased to $0.9 \mathrm{mg} / \mathrm{ml}$ after $24 \mathrm{~h}$ 
of fermentation, which is in accordance with the results published by Leite et al. [18]. The concentration of citric acid in the second phase of fermentation was almost constant with the average value of $1.24 \pm 0.05 \mathrm{mg} / \mathrm{ml}$ (Table 1). Citrates present the most favorable substrate for diacetyl formation, one of the main aroma components in fermented milk. The constant value of citric acid was also reported during the fermentation of kefir made by direct inoculation of kefir grains into the full fat pasteurized cow milk [6].

Malic acid was not detected at the beginning of fermentation, but it was observed after $13 \mathrm{~h}$ of fermentation of milk inoculated with kefir grains and after $6 \mathrm{~h}$ of fermentation of milk inoculated with kefir percolate, and remained at the level of $0.25-0.41 \mathrm{mg} / \mathrm{ml}$ (Table 1). Other investigation reported a higher concentration of malic acid in the kefir made from goat milk $(3.1 \mathrm{mg} / \mathrm{ml})$ than in the kefir made from cow milk $(0.1 \mathrm{mg} / \mathrm{ml})$ [21].

Similar was observed for acetic acid, detected in a very small concentration after $15 \mathrm{~h}$ and $12 \mathrm{~h}$ in the first and the second phase of fermentation, respectively (Table 1). According to the research of Soupioni et al. [22] acetic acid was usually detected after $18 \mathrm{~h}$ of the kefir fermentation.

\section{Conclusion}

Kefir represents a functional drink with potential probiotic properties. Monitoring of the chemical and microbiological composition can help to understand the changes which occur during the kefir fermentation. The activity of LAB led to the utilization of lactose and consequently, the production of lactic acid as the main metabolite causing the reduction of $\mathrm{pH}$ value. After the $\mathrm{pH}$ value drop, the yeasts number increased resulting in the increased $\mathrm{CO}_{2}$ content. The two-phase fermentation process for the kefir production resulted in similar changes of the $\mathrm{pH}$ value and number of $L A B$ at the end of fermentation. This process could allow the reduction of the time needed for the kefir production because microorganisms in kefir percolate are already adapted to the environment in the fermented kefir.

\section{Acknowledgements}

This work was supported by "CEI-Central European Initiative" within the project "PACKSENSOR".

\section{References}

[1] M. J. Chen, J. R. Lui, C. W. Lin, Y. T. Yeh, Study of the microbial and chemical properties of goat milk kefir produces by inoculation with Taiwanese kefir grains, Asian-Australasian Journal of Animal Sciences, 18(5) (2005) 711 - 715.

[2] T. Pogačić., S. Šinko, Š. Zamberlin, D. Samaržija, Microbiota of kefir grains, Mlijekarstvo , 63(1) (2013) 3 14. [In Croatian]

[3] R. F. Schwan, K. T. Magalhães-Guedes, D.R. Dias, in Fermented milk and dairy products, A. K. Puniya Ed., CRC Press, Boca Raton, Florida 2016, p. 462.

[4] E. R. Farnworth, I. Mainville, in Handbook of fermented functional foods, E. R. Farnworth Ed., CRC Press, Boca Raton, Florida 2008, p. 89.

[5] A. M. de Oliveira Leite, M. A. L. Miguel, R. S. Peixoto, A. S. Rosado, J. T. Silva, V. M. F. Paschoalin, Microbiological, technological and therapeutic properties of kefir: a natural probiotic beverage, Brazilian Journal of Microbiology, 44(2) (2013) 341 - 349.

[6] Z. B. Güzel-Seydim, A. C. Seydim, A. K. Greene, A. B. Bodine, Determination of organic acids and volatile flavor substances in kefir during fermentation, Journal of Food Composition and Analysis, 13(1) (2000) 35 - 43.

[7] J. H. Hotchkiss, B. G. Werner, E. Y. C. Lee, Addition of carbon dioxide to dairy products to improve quality: A comprehensive review, Comprehensive Reviews in Food Science and Food Safety, 5(4) (2006) 158 - 168.

[8] B. H. Stuart, Infrared spectroscopy - Fundamentals and Applications, John Wiley \& Sons, Sidney, 2004, p. 15.

[9] D. Savić., B. Danilović, L. Polleto, L. Cocola, M. Fedel, Gas content measurement in headspace of food packages on non-destructive manner, Glasnik hemičara, tehnologa i ekologa Republike Srbije, (2016) 25 - 33. [In Serbian]

[10] A. Klein, O. Witzel, V. Ebert, Rapid, time-division multiplexed, direct absorption-and wavelength modulationspectroscopy, Sensors, 14(11) (2014) 21497 - 21513.

[11] B. Danilović., D. Savić, L. Cocola, M. Fedel, L. Poletto, Determination of $\mathrm{CO}_{2}$ content in the headspace of spoiled yogurt packages, Journal of Food Quality, (2018) 1 - 6, Article ID 8121606.

[12] N. S. Oh, H. A. Lee, J. H. Myung, J. Y. Lee, J. Y. Joung, Y. K. Shin, S. C. Baick, Effect of different commercial oligosaccharides on the fermentation propreties in kefir during fermentation, Korean Journal for Food Science of Animal Resources, 33(3) (2013) 325 - 330.

[13] J. Zhou, X. Liu, K. Huang, M. Dong, H. Jiang, Application of the mixture design to design the formulation of pure cultures in Tibetan kefir, Agricultural Sciences in China, 6(11) (2007) 1383 - 1389.

[14] S. Otles, O. Cagindi, Kefir: a probiotic dairy-composition, nutritional and therapeutic aspects, Pakistan Journal of Nutrition, 2(2) (2003) 54 - 59.

[15] K. T. Magalhães., G. V. de Melo Pereira, C. R. Campos, G. Dragone, R. F. Schwan, Brazilian kefir: structure, microbial communites and chemical composition, Brazilian Journal of Microbiology, 42(2) (2011) 693 - 702.

[16] M. Bensmira, B. Jiang, Organic acids formation during the production of a novel peanut-milk kefir beverage, British Journal of Dairy Sciences, 2(1) (2011) 18 - 22.

[17] B. Kaptan, S. Kayisoglu, O. Oksuz, Mathematical modeling of $\mathrm{pH}$ variation as a function of temperature and time in kefir production, American Journal of Food Science and Nutrition Research, 2(2) (2015) 57 - 61.

[18] A. M. Leite, D. C. A. Leite, E. M. Del Aquila, T. S. Alvares, R. S. Peixoto, M. A. L. Miguel, J. T. Silva, V. M. F. Paschoalin, Microbiological and chemical characteristics of Brazilian kefir during fermentation and storage processes, Journal of Dairy Science, 96(7) (2013) 4149 - 4159.

[19] C. Garofalo, A. Osimani, V. Milanović, L. Aquilanti, F. De Filippis, G. Stellato, S. Di Mauro, B. Turchetti, P. Buzzini, D. Ercolini, F. Clementi, Bacteria and yeasts microbiota in milk kefir granis from different Italian regions, Food Microbiology, 49 (2015) 123 - 133.

[20] A. A. Ismaiel, M. F. Ghaly, A. K. El-Naggar, Some physicochemical analysis of kefir produces under different fermentation conditions, Journal of Scientific \& Industrial 
Research, 70(5) (2011) 365 - 372.

[21] G. Turker, B. Kizilkaya, N. Arifoglu, Determination of organic acid composition and free radical scavenging capacity of kefir, Asian Journal of Chemistry, 26(8) (2014) $2443-2446$.

[22] M. Soupioni , K. Vlachou, A. Psarologou, A. Bekatorou, Abating whey organic load through ethanol and lactic acid production by kefir, Toxicological \& Enviromental Chemistry, 98(10) (2016) 1191 - 1199.

Izvod

\section{MIKROBIOLOŠKE I HEMIJSKE PROMENE TOKOM DVOSTEPENE FERMENTACIJE KEFIRA}

Kefir predstavlja fermentisani mlečni proizvod čija komercijalna proizvodnja intenzivno raste zbog njegovog povoljnog uticaja na ljudsko zdravlje. Proizvodi se kombinovanom alkoholnom i mlečno-kiselinskom fermentacijom do kojih dolazi usled aktivnosti mikrobiote kefirnih zrna. Aktivnost bakterija mlečne kiseline i kvasaca koji su prisutni u kefirnim zrnima utiče na mikrobiološke i hemijske promene tokom fermentacije. $U$ ovom radu su opisane promene koje nastaju tokom dvofazne fermentacije kefira pomoću takozvane „Ruske metode”. Tokom dvofazne fermentacije kefira primećeno je povećanje broja bakterija mlečne kiseline i kvasaca. Aktivnost bakterija mlečne kiseline dovodi do nakupljanja organskih kiselina i smanjenja pH vrednosti. Ovaj proces je praćen smanjenjem sadržaja laktoze kao glavnog izvora energije potrebne za rast mikroorganizama. Sa druge strane, prisustvo kvasaca u kefiru dovodi do povećanja sadržaja $\mathrm{CO}_{2}$ tokom obe faze fermentacije. Primena ovog dvofaznog procesa može smanjiti vreme potrebno za proizvodnju kefira bez uticaja na smanjenje poželjnih senzornih karakteristika.
Ključne reči: kefir, kefirna zrna, bakterije mlečne kiseline, kvasci, hemijske promene 